\title{
Impact of Inquiry Learning Method on the Grammatical Accuracy of Iranian EFL Learners' Writing
}

\section{Shahla Tavanapour ${ }^{1} \&$ Azizeh Chalak ${ }^{1 *}$}

\author{
* Correspondence: \\ azichalak@gmail.com \\ 1. English Department, Isfahan \\ (Khorasgan) Branch, Islamic Azad \\ University, Iran
}

Received: 2 June 2021

Revision: 25 July 2021

Accepted: 22 August 2021

Published online: 20 September 2021

\begin{abstract}
Writing as one of the important skills needed for communication has always been the topic of research in English teaching contexts. To improve the writing of English students, teachers employ different methods. This study was designed to investigate the impact of the inquiry learning method on the grammatical accuracy of Iranian EFL learners' writing. To do so, 90 intermediate EFL learners from Abadan Medical University were selected through the Oxford Placement Test (OPT) and participated in a quasiexperimental study, and then they were randomly divided into experimental and control groups (EG \& CG). Their ages ranged between 20 to 30. A pretest was administered to compare the results of their performance at the beginning of the study. The inquiry learning method was taught to the EG as the treatment, while the conventional method was employed for the CG. In the experimental class, the teacher did not teach everything directly, and the learners were expected to discover the knowledge and generate rules, but the presentation of materials in the $\mathrm{CG}$ was conventional without any discussion, and the students in the CG were mainly passive. After the instruction, a posttest was given to both groups to observe the impact of the inquiry learning method on the grammatical accuracy of their writings. The analysis of the data was accomplished through the application of a dependent sample $t$-test and an independent-samples $t$-test to compare the mean scores, and the results indicated that the inquiry learning method improved the EGs' writing, and they outperformed the CG. The findings of this study could have implications for the EFL learners, teachers, and material designers that may help them in EFL language learning and teaching.
\end{abstract}

Keywords: conventional method, inquiry learning method, Iranian EFL learners, language learning, writing 


\section{Introduction}

Writing is a tool for communication (Haklau, 2002), and to write a comprehensive text, letters must be combined in a particular order to form words, phrases, clauses, and sentences (Linsday \& knight, 2007). Three basic skills are essential for writing: (a) the ability to use the accepted standards of conventions, such as spelling, punctuation, and capitalization; (b) linguistic ability to use syntactic, morphological, and semantic components; and (c) the cognitive ability to state feeling, preferences, and ideas in a creative manner (Hammill \& Larsen, 1996). Chastain (1998) believed that writing is one way to communicate with those who know the language. Writing has communicative purposes and it is a negotiation between reader and writer.

Without cognitive and meta-cognitive strategies, writing may not be learned because it is a difficult activity (Hubner et al., 2010). There are different techniques and strategies for developing writing and one of them is the inquiry learning method. Fauziati (2014) defined inquiry as a process of searching for information or truth through some questions. Based on this, the students propose some questions and find the answers with help of their teacher and classmates. Prince and Felder (2006) pointed that inductive learning to some extent is similar to the inductive approach, problem-based learning, discovery learning, and project-based learning. The inquiry learning method included some activities such as scaffolding, formative assessments, critical thinking, and questioning (Friesen \& Scott, 2013).

Graham and Perin (2007) believed that the inquiry learning method helps learners to develop ideas for particular writing tasks and it is a kind of technique for improving their writing. As the name suggests, inquiry learning methods are based on some questions for presenting instructions. In the inquiry learning method, teachers do not teach everything directly, but learners are expected to learn the knowledge through discovery learning, and learners maximize their learning by working together. That means, in the inquiry learning method, teachers present material by questioning, and materials are not taught directly or explicitly by the teacher. Instead, learners discover knowledge and rules based on a series of examples. Teachers act as a facilitator to help learners to explore in constructing conception and teacher speaks less in class when compared with their roles in the teacher-centered classes. It is evident that this type of teaching challenges students and raises their critical thinking. In short, the inquiry learning method is based on these principles: ask, investigate, create, discuss, and reflect (Chuang \& Wang, 2001).

\subsection{Statement of the Problem}

Learning English includes four skills; listening, speaking, reading, and writing. Writing is the most difficult skill among others. People need this skill to express their feelings, describe something, discuss an idea, present a point of view, and share the experience. Although many students are able to read well, most of them can't write a connected and well-structured essay. Writing is a difficult task because the students have to arrange words to be grammatical sentences. Improving writing should be the main concern of not only the English as a Foreign Language (EFL) learners, but also those who want to learn English and improve their writing in and outside the academic settings. Hubner et al. (2010) claimed that it is not easy to achieve proficiency in foreign language writing in the educational environment. As many EFL learners don't want to write because of making errors, lack of proficiency, judgment by the teacher or other students, and negative feedback, teachers have to find a suitable and effective method to improve the EFL learners' writing. One of the methods is inquiry-based instruction. When learning is based on cooperation, the learners have more opportunities to negotiate their strengths and weakness. In this regard, communicative activities can motivate the learners and make good relationships between the teacher and the EFL learners, and cooperation encourages a supportive environment for language learning. Therefore, this study aims to find out the impact of the inquiry learning method on the grammatical accuracy of Iranian EFL learners' writing.

Previous studies have shown the usefulness of the inquiry learning method in educational contexts such as improving learners' speaking skills, increasing their self-esteem, and involving them in the learning process (Irham \& Jayanti, 2020). Some studies (Irham \& Jayanti, 2020; Ismailov, 2021; Rejeki, 2017) have found that the inquiry learning methods are more effective for educational purposes, while others have concluded that the conventional methods are more useful in the teaching and learning process (Brickman et al., 2009). As there are inconsistencies and differences in the results of previous research about the effect of the inquiry learning method in the educational contexts, this study intended to investigate the impact of the inquiry learning method on the grammatical accuracy of Iranian EFL learners' writing. This study may be important for Iranian EFL learners because the use of the inquiry learning method may help better improvement in the EFL learners' writing in the educational environment. This may reinforce learners' 
motivation to write in class and it encourages learners to develop their writing and give them a chance to express their feelings and opinions to communicate with other students.

\section{Literature Review}

The inquiry learning method helps the students to be active partners in class and allows developing their intellectual potency through their efforts to build new understanding, meaning, and knowledge. Students can help each other to learn better by an inquiry learning method (Deboer, 2006). It can promote the development of higher-order intellectual and academic skills through student-driven questions (Cox et al., 2007). A study was conducted by Yilee (2014) to investigate the effect of the inquiry learning method in the process of second language learning. In this study, a questionnaire was given to students to assess their feedback on the effectiveness of this approach, and favorable findings were revealed. Students expressed their interest in the inquiry learning method and the result showed that this approach helps their language learning. Results also showed that the inquiry learning method enhances students' classroom involvement. Another study was conducted by Arauz (2013), in this study, the researcher considers the effect of the inquiry learning method as an active model for English as a foreign language class. Teachers provided opportunities for students to construct their knowledge, through the inquiry learning method, and integration of technology in the curriculum, students could improve their social skills.

Eurgul and Simsekli (2011) studied the effect of the inquiry learning method on elementary school students' processes and attitudes. For this purpose, pretest and posttest were administered to students and were randomly selected as control and experimental groups. The study was conducted during the two semesters. The results of the study showed that the inquiry learning method could enhance students' skills and attitudes. Another study was conducted by Abdi (2014) to investigate the effects of inquiry-based learning (IBL) methods on students' academic achievement in lessons. Students were selected through the purposive sampling method. The teacher taught the experimental group (EG) through an inquiry learning method while the control group (CG) was traditionally instructed. This treatment lasted about eight weeks. Two tests were administered as the pre-test and post-test to determine the effectiveness of the inquiry learning method over the traditional instruction. The result revealed that the EG who was instructed through the inquiry learning method achieved higher scores than one who was instructed through the traditional method.

Duram (2015) studied the effect of activity set developed according to the IBL approach on students' critical thinking skills in science and technology courses. Within the framework of the study, to evaluate the effects of the IBL approach on students' critical thinking skills in science and technology courses, the guided activity set was developed by the researchers in line with the IBL approach. In this study, pretest and posttest were administered to experimental and control groups. The findings of the study revealed the science and technology to learning supported with the IBL approach had significant effects on students' critical thinking skills in science and technology courses. Another study was conducted by Al-wadi (2018) to examine whether using inquiry-based teaching supports EFL students' learning of theoretical English context. The design of the study was quasi-experimental research through a one-independent group design in a class of 19 EFL learners in Bahrain. A survey was conducted before and after treatment to evaluate the EFL learners' motivation towards inquiry learning. The results of collecting data showed that inquiry-based teaching had a positive impact on increasing those EFL and ESL learners' motivation.

Wale and Bishaw (2020) considered the impact of utilizing the IBL on learners' critical skills. The design of the study was quasi-experimental and participants were 20 EFL learners who took advanced writing skills courses. The instruments for collecting data were a series of three argumentative essays as the pretest and posttest. The instruction was based on an inquiry learning method in which students observed, predicted, proposed some questions, examined, analyzed, and then predicted and discussed the findings. The results presented that inquiry-based learning improved students' critical thinking skills. In recent years, there has been an increasing amount of literature (Irham \& Jayanti, 2020; Ismailov, 2021; Rejeki, 2017) on using the inquiry learning method in EFL classes. Irham and Jayanti (2020) studied the effect of using the inquiry learning method on students' speaking improvement. The data were collected through an oral presentation test, questionnaire, field-note, and interview. The results showed that using the inquiry learning method not only improved their speaking skills, but also increased their self-esteem and involved them in the learning process.

Within the context of Iran, Ghaemi and Mirsaeed (2017) conducted a study to consider the impact of the inquiry learning approach on the critical thinking skill of EFL students. The participants were from Guyesh language institute in Alborz, Iran. They were randomly divided into two groups; experimental and control groups. After treatment, a posttest was administered to both groups for collecting data. The results revealed that the inquiry learning method 
increased the critical thinking of the subjects. Although several works (Abdi, 2014; Al-Wadi, 2018; Nurtalina, 2013; Wale \& Bishaw, 2020) have been done about inquiry-based language teaching, to the best of the researchers' knowledge, very few studies have been conducted to investigate the impact of the inquiry learning method on the grammatical accuracy of Iranian EFL learners' writing. Therefore, this research aims to consider the impact of the inquiry learning method on the grammatical accuracy of Iranian EFL learners' writing. Based on the aim of this study, the following research questions have been posed:

1. Does the inquiry learning method have any significant effect on the grammatical accuracy of Iranian EFL learners in their writings?

2. Is there any significant difference between the inquiry learning method and conventional language teaching on improving accuracy?

\subsection{Research Hypotheses}

The present study proposed the following null hypotheses based on the above research questions:

HO1. The inquiry learning method does not have any significant effect on the grammatical accuracy of Iranian EFL learners in their writings.

$\mathrm{HO}$. There is not any significant difference between the inquiry learning method and conventional language teaching on improving accuracy.

\section{Methodology}

\subsection{Design and Context of the Study}

A quasi-experimental design was used in the current research. The participants were selected through available sampling and then were randomly divided into two groups. The study was conducted at the Medical University, Abadan, Khuzestan, Iran during Autumn, 2019. The main goal of the study was to consider the impact of the inquiry learning method on the grammatical accuracy of Iranian EFL learners' writing.

\subsection{Participants}

The students who participated in this study included 90 students from Abadan Medical University. All the participants were sophomore students. They were majoring in Medicine. The homogeneity test, OPT (Oxford Placement Test), was administered to the students to indicate their homogeneity. Then, 60 students whose scores were one standard deviation above and below the mean were selected as the participants of the study and they were randomly divided into experimental and control groups.

Table 1. Demographic background of the participants

\begin{tabular}{ll}
\hline No. of Students & 60 EFL learners \\
\hline Gender & 30 Females \& 30 Males \\
\hline Native Language & Persian and Arabic \\
\hline University & Medical University, Abadan, Khuzestan, Iran \\
\hline Major & Medicine \\
\hline Academic Years & Autumn, 2019 \\
\hline
\end{tabular}

\subsection{Instruments}

Several instruments were used in the process of this research. The first one was the Oxford placement test (OPT) to determine the homogeneity of groups at the intermediate level. The reliability of this test was computed through a KR-21 formula to make sure of the sample population homogeneity $(\mathrm{r}=0.87)$. The second test was a pretest that 
measured the students' writing before treatment. The test included three topics. Each of the students was asked to choose one of the topics and write an essay that included at least 150 words. The third test was a posttest to see if there was any improvement in learners' writing ability after the treatment. The posttest included three topics. Each of the students was also asked to choose one of the topics. The total of the pre-test and post-test was 20 . The essays were scored by two raters and to account for inter-rater reliability of the pretest and posttest, Pearson correlation coefficients were estimated. The inter-rater reliability of the pretest and posttests is illustrated in Table 2.

Table 2. The inter-reliability of the pretest and posttest of the EG and CG

\begin{tabular}{lll}
\hline & EG & CG \\
\hline Pretest & 0.79 & 0.78 \\
\hline Posttest & 0.89 & 0.83 \\
\hline
\end{tabular}

\subsection{Materials}

The materials that were afforded to students was College Writing developed by Zemach and Rumisek (2003). The materials for the two groups were the same. In every session, the teacher in the CG taught one chapter of the book conventionally, but in the EG, the same chapter was taught by employing the inquiry learning method.

\subsection{Data Collection Procedure}

For this study, 90 male and female medical students who studied EGP at Abadan Medical University were selected. The subjects were taken a test to determine their homogeneity regarding their levels of proficiency at the intermediate level, based on the Oxford Placement Test and 60 learners whose scores were one standard deviation above and below the mean were selected, and then they were randomly divided into experimental and control groups (EG \& CG). Each session lasted about 30 minutes. The whole research project lasted about 14 sessions, and the first and last sessions were pre and post-test and the material for the EG and CG was the same. In the EG, teaching was based on the inquiry learning method that the teacher asked some questions for presenting instructions. The instructor posed a question and students devised procedures such as discussion, pair work, and group work to answer questions. In this method, the teacher did not teach everything directly, but learners were expected to discover the knowledge, to generate rules based on some examples and they were active not passive.

In other words, the materials were not taught directly or explicitly by teachers, but they were presented by questioning. Teachers acted as facilitators and directors to help learners to explore constructing conception. Teaching in the EG was based on discovery learning and learner-centered rather than teacher-centered. In the EG, the learners proposed some questions rather than just listened to the teacher. Therefore, they needed more competence and proficiency. Learners were knowledge inquirers rather than knowledge receivers. On the other hand, the CG's presentation of the materials was based on conventional ways. Students in the CG were passive and the class was teacher-centered. In this class, there wasn't any discussion and interaction among learners, and in this group, the teacher applied the traditional lecture method as a means of instruction.

\subsection{Data Analysis Procedure}

In this research, all the scores were entered into SPSS software. The quantitative data of this research were analyzed by using statistical methods. This technique was used to find any possible significant differences between the students' writing before and after the inquiry learning method and also between the post-test scores of the control and experimental groups. For understanding whether the inquiry learning method had any significant effect on the grammatical accuracy of Iranian EFL learners in their writings, a dependent sample $t$-test was used. Then, to understand there was any significant difference between the inquiry learning method and conventional language teaching for improving grammatical accuracy in their writings on the pretest and posttest, an independent-samples $t$ test was utilized.

\section{Results}


The main goal of this study was to investigate the impact of the inquiry learning method on the grammatical accuracy of Iranian EFL learners' writing. The first research question of this study examined whether the inquiry learning method has any effect on the grammatical accuracy of Iranian EFL learners' writing; so that to compare pre-test and post-test scores of the learners in the EG, a paired-samples $t$-test was used. Table 3 shows the descriptive statistics of the participants' performance in the EG on pre-test and post-test

Table 3. Results of descriptive statistics comparing the pretest and posttest scores of the EG

\begin{tabular}{|c|c|c|c|c|}
\hline & $\mathrm{N}$ & Mean & Std. Deviation & Std. Error Mean \\
\hline Pretest & 30 & 10.10 & 2.09 & .38 \\
\hline Posttest & 30 & 18.43 & .68 & .12 \\
\hline
\end{tabular}

The mean of the EG on pre-test and post-test were 10.10 and 18.43 respectively. To determine whether the difference between these two mean scores was statistically significant or not, the researchers had to conduct the paired-samples $t$-test table below:

Table 4. Results of paired-samples $\mathrm{T}$-test comparing the pretest and posttest scores of the EG

\begin{tabular}{|c|c|c|c|c|c|c|c|}
\hline & \multirow{2}{*}{$t$} & \multirow{2}{*}{$D f$} & \multirow{2}{*}{$\begin{array}{l}\text { Sig. } \\
\text { (2-tailed) }\end{array}$} & \multirow{2}{*}{$\begin{array}{l}\text { Std. } \\
\text { Deviation }\end{array}$} & \multirow{2}{*}{$\begin{array}{l}\text { Std. Error } \\
\text { Mean }\end{array}$} & \multicolumn{2}{|c|}{$\begin{array}{l}95 \% \text { Confidence Interval } \\
\text { of the Difference }\end{array}$} \\
\hline & & & & & & Lower & Upper \\
\hline EG Pretest-Posttest & -.24 & 29 & .000 & 1.90 & .35 & -9.15 & -7.71 \\
\hline
\end{tabular}

As shown in Table 4, there was a significant difference between the pre-test and post-test scores of the EG since the $p$-value was smaller than the specified level of significance $(0<5)$. This provided a positive answer to the first research question of the study "Does the inquiry learning method have any significant effect on the grammatical accuracy of Iranian EFL learners' writing?" Thus, it was revealed that the inquiry learning method had played a positive effect on helping Iranian EFL learners to improve their grammatical accuracy writing. To answer the second research question, the researchers had to compare the writing post-test scores of the EG and CG, for which an independent-samples $t$ test could be conducted.

Table 5. Descriptive statistics of post-test scores of the EG and CG

\begin{tabular}{llllll}
\hline & Groups & $N$ & Mean & Std. Deviation & Std. Error Mean \\
\hline \multirow{3}{*}{ Pretest } & EG & 30 & 10.10 & 2.09 & .38 \\
\cline { 2 - 6 } & CG & 30 & 9.23 & 2.60 & .47 \\
\hline \multirow{3}{*}{ Posttest } & EG & 30 & 18.43 & .68 & .12 \\
\cline { 2 - 6 } & CG & 30 & 14.96 & .76 & .13 \\
\hline
\end{tabular}

In Table 5, it could be found that the post-test mean score of the EG was larger than the post-test mean score of the CG. To see whether this difference was a statistically significant one or not, the researchers had to look down the Sig. column and in front of the Groups row in Table 6. 
Table 6. Results of the independent-samples T-test for comparing the EG and CG scores on the pretest and posttest Levene's Test for Equality of Variances $t$-test for Equality of Means

F Sig. $\quad t \quad d f \quad$ Sig. (2-tailed)

\begin{tabular}{crccccc}
\hline \multirow{2}{*}{ Pretest } & Equal variances assumed & 2.76 & .10 & 1.42 & 58 & .16 \\
\cline { 2 - 7 } & Equal variances not assumed & & & 1.42 & 55.36 & .16 \\
\hline \multirow{2}{*}{ Posttest } & Equal variances assumed & .01 & .91 & 13.72 & 58 & .000 \\
\cline { 2 - 7 } & Equal variances not assumed & & & 13.72 & 57.24 & .000 \\
\hline
\end{tabular}

Table 6 shows that the $p$-value was smaller than the alpha level of significance $(.009<.05)$, which indicates that the difference between the two groups of EG and CG in the writing post-test was statistically significant. The results for the second research question are graphically represented in Figure 2.

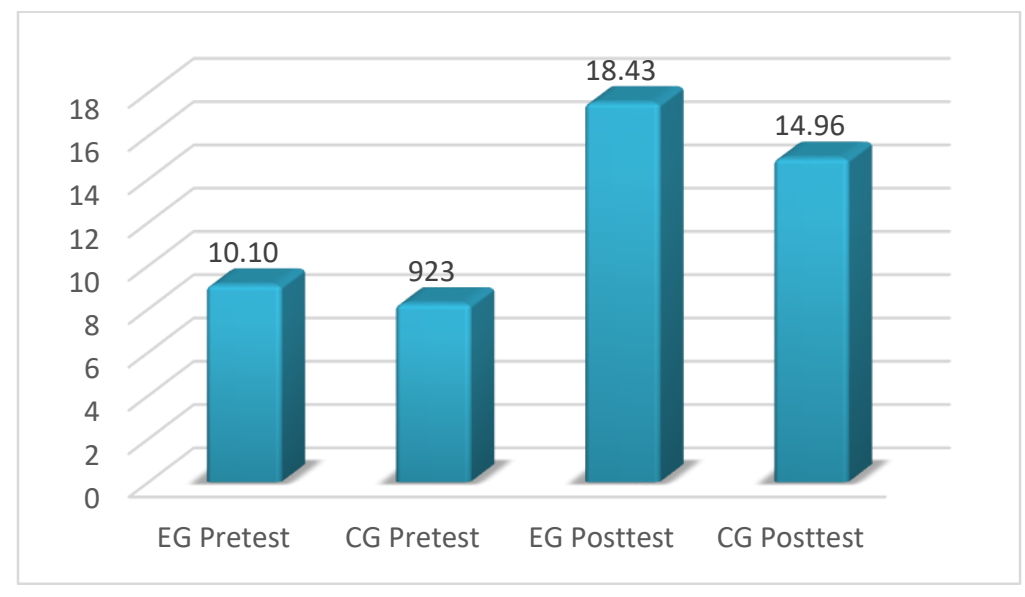

Figure 2. Post-test mean scores of EG and CG.

As it can be seen in Figure 2, on the post-test, the EG significantly outperforms the CG on the post-test of writing.

\section{Discussion}

In this study, the researchers utilized the inquiry learning method for improving the grammatical accuracy of Iranian EFL learners' writing. Based on the results, it can be said that the inquiry learning method had a significant effect on learners' writing among the EFL learners. Moreover, analyzing the data showed that there was a considerable difference between the two performances of the experimental group in pre and post-tests. As shown in Table 4, there was a statistically significant difference between the pre-test and post-test scores of the experimental group since the p-value was smaller than the specified level of significance. This shows the positive answer to the first research question of the study. Therefore, it was revealed that the inquiry learning method had played a positive effect on the writing of students.

The finding of this study agrees with Graham and Perin's (2007) study that the inquiry learning method helped them to develop ideas for particular writing tasks and it was a kind of technique for teaching writing. In other words, students constructed their recognition of the world. Students could help each other to learn better by an inquiry learning method (Deboer, 2006). Learning was deeply rooted in profound thinking and thinking was inspired by 
questions. The findings are in agreement with that of Eurgul and Simsekli (2011) who studied the effect of the inquiry learning method on elementary school students' processes and attitudes. The results of the study showed that the inquiry learning method can enhance students' skills and attitudes.

After analyzing the data, the results showed that there was a significant difference between students' writing in the post-test. As shown in Table 5, the results of the post-test showed that the two groups were not homogeneous at the end of the treatment period. Thus, there was a significant difference between the two groups. The EG outperformed the CG on the post-test. As it was observable, the inquiry learning method was beneficial for developing writing. It is in alignment with the study of Abdi (2014) who investigated the effects of the inquiry learning method on students' academic achievement in lessons. The results showed that students who were instructed through the inquiry learning method achieved higher scores than the ones who were instructed through traditional methods. However, it is not in line with the studies of Brickman et al. (2009) who found that through inquiry students' literacy and research skills have improved, but these students gained less self-confidence in scientific abilities compared to the traditional students.

The use of the inquiry learning method has been debated amongst educators for over one hundred years. Research has pointed towards the inquiry learning method as a teaching method, process, or philosophy. It has always been based on a constructivist paradigm that upheld learners as active participants in the learning process who constructed their understandings of the world around them by incorporating past experiences and knowledge (Brown \& Adams, 2001). The inquiry learning method is different from the teacher-based instruction because of focusing on the role of the learners personal interpretations of knowledge based on their previous experience and application of knowledge in a relevant context.

\section{Conclusion}

This study began with the assumption that the inquiry learning method can improve the grammatical accuracy of Iranian EFL learners' writing. The research employed using the inquiry learning method during treatment for the EG, but the participants in the control group were taught writing by the conventional method. After the post-test, the results indicated that both inquiry learning and conventional methods affect learners' knowledge of writing, but the performances of the EG were better than the CG. However, it could be concluded that the conventional method was not very effective as much as the inquiry learning method in the EFL contexts. Taking the results of the data analysis and the probable reasons into consideration, one can come up with the illuminating importance of the inquiry learning method. The conventional method did not seem to be effective in developing writing since the traditional activities that they learned in English classes make them passive in the classroom and the conventional class in writing used pen and paper activities rather than inquiry. The conclusions that can be made are (a) Using the inquiry learning method should be highly emphasized where developing writing is the focus of the study, (b) Teaching writing conventionally in the CG, though was less significant than the EG in this study, should also be utilized as the second priority in teaching writing in class. All in all, it may be concluded that when language learners are given the autonomy to pursue their practices directed at answering questions not only do they become more confident but also they become more accurate and articulate in their writing practices. It seems quite wise to let language learners get engaged with the issues raised in language classrooms as researchers and inquirers instead of passive receivers of already established knowledge.

Based on the research findings, this study gives the following implications and suggests some ideas for the EFL learners, teachers, and material designers that may help them in the EFL language learning and teaching. By taking insights from the present study, the EFL teachers might include inquiry, discussion, interaction, negotiation, and needs of learners in classes. The results of this study showed that the more effective method could be the use of the inquiry learning method in teaching writing. In the EFL context, a teacher should provide opportunities for students to raise their level of motivation and interest, and this may be more easily realized through the inquiry learning method. The researchers faced several limitations in this study. Firstly, the small size of the research populations in each group because if there were more participants, the results could be more generalizable. Secondly, the time for the instructions was so limited. Thirdly, the role of the variable such as gender, motivation, and anxiety was not found in this study. The present study was undertaken to examine the impact of the inquiry learning method on the grammatical accuracy of Iranian EFL learners' writing. Since this study was conducted on medical students who studied EGP at Abadan Medical University, some investigations could be conducted on the English major students. The present study has been carried out at the intermediate level language learners. Succeeding studies may evaluate the inquiry learning 
method in teaching writing to advanced and elementary language learners. This study was conducted to measure the improvement of grammatical accuracy of Iranian EFL learners' writing. Further research can be done regarding the effect of the inquiry learning method on other skills and sub-skills such as reading, speaking, and vocabulary.

\section{References}

Abdi, A. (2014). The effect of inquiry-based learning method on students' academic achievement in a science course. Universal Journal of Educational Research, 2(1), 37-41. https://doi.org/10.13189/ujer.2014.020104

Al-Wadi, H. (2018). Supporting EFL students' learning of theoretical English content through using an inquiry-based teaching technique. English Language Teaching, 11(8), 73-85. https://doi:10.5539/elt.v11n8p73

Arauz, P. E. (2013). Inquiry-based learning in an English as a foreign language class: A proposal. Revista de Lenguas Modernas, 19, 479-485. https://revistas.ucr.ac.cr/index.php/rlm/article/view/14031/13337

Brickman, P., Gormally, C., Hallar, B., \& Armstrong, N. (2009). Effects of inquiry-based learning on students' science literacy skills and confidence. International Journal for the Scholarship of Teaching and Learning, 3(2), 122. https://doi.org/10.20429/ijsotl.2009.030216

Brown, J. C., \& Adams, A. (2001). Constructivist teaching strategies: Projects in teacher education. Charles C. Thomas.

Cox, A., Webber, S., Levy, P., \& Stordy, P. (2007). Blogging to support inquiry-based learning (IBL). Sheffield.

Deboer, G. E. (2006). Historical perspectives on Inquiry teaching in schools. In L. B. Flick, \& N. G. Lederman (Eds.), Scientific inquiry and nature of science: Implications for teaching, learning, and teacher education (pp. 1735). Springer.

Duram, M. (2016). The effect of the inquiry-based learning approach on student's critical-thinking skills. Eurasia Journal of Mathematics, Science \& Technology Education, 12(12), 2887-2908. https://www.ejmste.com/article/the-effect-of-the-inquiry-based-learning-approach-on-students-criticalthinking-skills-4639

Eurgul, R., \& Simsekli, Y. (2011). The effects of inquiry-based science teaching on elementary school students' science process skills and science attitudes. Bulgarian.

Fauziati, E. (2014). Methods of teaching English as a foreign language (TEFL): Traditional method designer methods communicative methods scientific approach. Era Pustaka Utama.

Friesen, S., \& Scott, D. (2013). Inquiry-based learning: A review of the research literature. Alberta Ministry of Education.

Ghaemi, F., \& Mirsaeed, S. (2017). The impact of inquiry-based learning approach on critical thinking skill of EFL students. EFL Journal, 2(2), 89-102. https://pdfs.semanticscholar.org/f357/08f9b1829b93b4487c4720fe3aaa3d5b1e80.pdf?_ga=2.169867746.21 32991023.1629918105-892640681.1592567717

Graham, S., \& Perin, D. (2007). Writing next: Effective strategies to improve the writing of adolescents in middle and high Schools - a report to Carnegie Corporation of New York. Alliance for Excellent Education.

Hammill, D. D., \& Larsen, S. C. (1996). Test of written language (3rd Ed.). Pro-Ed.

Harklau, L. (2002). The role of writing in classroom second language acquisition. Journal of Second Language Writing, 11(4), 329-350. https://doi.org/10.1016/S1060-3743\%2802\%2900091-7

Hubner, S., Nuckles, M., \& Renkl, A. (2010). Writing learning journals: Instructional support to overcome learningstrategy deficits. Learning and Instruction, 20(1), 18-29. https://doi.org/10.1016/j.learninstruc.2008.12.001

Irham, I., \& Jayanti, S. D. (2020). Inquiry-based learning for students' speaking skill improvement: Voices and realities from the ground. Journal of English for Academic and Specific Purposes (JEASP), 3(2), 82-91. doi: https://doi.org/10.18860/jeasp.v3i2.11120 
Ismailov, M. (2021). Conceptualizing an inquiry-based lingua-cultural learning through telecollaborative exchanges [version 1; peer review: 2 approved]. https://doi.org/10.12688/f1000research.55128.1

Lindsay, C., \& Knight, P. (2007). Learning and teaching English: A course for teachers. Oxford University Press.

Nurtalina. M. (2013). The effect of using inquiry-based learning strategy in the writing ability of the Eighth-grade students of SMP Negeri 1 Prambanan KlatenBVC. Masters thesis, English Education Department Faculty of Languages and Arts State University of Yogyakarta. http://eprints.uny.ac.id/18489/1/Nurtalina\%2007202244098.pdf

Prince, M. J., \& Felder, R. M. (2006). Inductive teaching and learning methods: Definitions, comparisons, and research bases. Journal of Engineering Education, 95(2), 123-138. https://doi.org/10.1002/j.21689830.2006.tb00884.x

Rejeki, S. (2017). Inquiry-based language learning (IBLL): theoretical and practical views in English classroom. English Franca, 1(2), 135-148.

Wale, B., \& Bishaw. K. (2020). Effects of using inquiry-based learning on EFL students' critical thinking skills. AsianPacific Journal of Second and Foreign Language Education, 5(9) 1-14, https://doi.org/10.1186/s40862-02000090-2

Yi Lee, H. (2014). Inquiry-based teaching in second and foreign language pedagogy. Journal of Language Teaching and Research, 5(6), 1236-1244. https://doi.org/10.4304/JLTR.5.6.1236-1244

Zemach D., \& Rumisek L. A. (2003). College writing from paragraph to essay. London: Macmillan. 